\title{
RESPONSES TO THE INTERNATIONALISATION OF HIGHER EDUCATION IN LANGUAGE POLICIES OF ESTONIA AND LATVIA
}

\author{
Kerttu Kibbermann \\ University of Latvia
}

\begin{abstract}
This paper analyses language policies in higher education in Estonia and Latvia. Both countries are currently in search for a balance between national and international in the sphere of higher education. Higher education in Estonia and Latvia mainly functions in the official languages of the countries, Estonian and Latvian. Yet, the international nature of tertiary education has brought these languages into contact with others, mostly English and Russian. The paper seeks to find out how the relationship of internationalisation and language is construed in state-level policy documents comparatively in Estonia and Latvia. The results of the analysis show that the issues of language are more thoroughly covered in Estonian policy documents than Latvian policy documents. However, in both countries internationalisation is mostly driven by the need to attract foreign students in order to fill the domestic demographic gap. Thus, both Estonia and Latvia connect internationalisation mostly to foreign-medium instruction.
\end{abstract}

Keywords: internationalisation of higher education, language policies, state-authored policy-planning documents, medium of instruction, English-medium instruction

DOI: https://doi.org/10.12697/jeful.2017.8.1.06

\section{Introduction}

Since the end of the 20th century, the internationalisation of higher education has prompted public and private, political and scientific debates on language matters in academia. On the one hand, publicly funded tertiary education is often perceived as part of national education systems in which the official/national language of the country should be used. Furthermore, using a language in higher education accords it prestige as only a small part of world languages enjoys being used academically. On the other hand, higher education is closely linked to science and research that are international by nature. Moreover, today's higher education has become international also at other levels, for example, at 
the teaching level. Universities are now actively engaging in processes of internationalisation: they adopt roles of international businesses and form part of a common trade market that is dominated by competition for students and faculty. Language-wise, internationalisation is manifested in the increasing use of English in academic settings where it has never before been used so extensively.

This paper contributes to the discussion by examining how internationalisation and language matters are handled in Estonian and Latvian state-authored policy documents. More specifically, it seeks an answer to the following question: How is the relationship of the internationalisation of higher education and language construed in stateauthored policy-planning documents in Estonia and Latvia? The paper is macrosociolinguistic in nature, namely, it studies language policy. According to Spolsky (2004, 2009), language policy can be analysed from three interrelated perspectives: (1) language policy (what he prefers to call language management), (2) language practices, and (3) language ideologies. This paper focuses on policymaking at the national level in order to highlight how the states depict the desirable linguistic situation in higher education; for further discussion on the multi-layered nature of top-down language policies in Estonia and Latvia, see e.g. SolerCarbonell et al. (2016).

\section{Internationalisation of higher education and language matters}

In Europe, particular stress within processes of internationalisation is put on academic mobility. The logic underlying the considerable emphasis laid on mobility is the following: the best students are considered to choose the best universities, i.e. the more international students, the higher the quality of education (Jensen and Thøgersen 2011: 19). Moreover, internationalisation is crucial as it brings in new students desperately needed for improving the bleak demographic outlook of many European countries (Hazelkorn 2011). This makes internationalisation largely a matter of economics. In addition, internationalisation, either abroad or at home, is almost automatically considered to improve students' language and cultural skills and provide them with better opportunities in the labour market (Coleman 2006: 5, Lam and Wächter 2014: 18, Saarinen and Nikula 2013: 139).

Mobility connects internationalisation directly to English-medium teaching. The large-scale study by Wächter and Maiworm (2014) confirms that attracting international students is a major reason why 
countries that are notEnglish-speaking have introduced English-medium teaching: universities are interested in the English-medium instruction mainly in order to "remove language obstacles from the enrolment of foreign students" (p. 18). As discussed above, internationalisation, mobility, and English-medium studies tend to be seen as quality markers of education. However, Hultgren (2014) concludes in her study about the relationship between the extent to which English is used in academia and the position a university holds in the international ranking lists that there is no statistically significant correlation between the use of English and world rank.

Setting up English-medium degree programmes in higher education means that support for the language has to be strong not only worldwide but also in the local society (Saarinen and Nikula 2013: 134). Haberland and Preisler (2015: 24) argue that the rapid growth in the number of English-medium degree programmes cannot be explained only with the top-down policies adopted by universities, states, and the EU. According to them, the grass-root motivation of young people to learn and use English - a highly prestigious language in their eyes - is at least equally as important. Indeed, English is the most widely taught language in secondary education all over the world (Maiworm and Wächter 2014: 26).

Language use in academia is sometimes perceived to be homogeneous. However, Hamel (2006: 104-105) suggests that there are three large areas to keep apart, i.e. production of knowledge (e.g. conducting research, work with informants, producing, interpreting and writing up data, communicating via e-mail); circulation of knowledge (e.g. reading research texts, listening to others, distributing one's own research results to others, either orally or in a written format) and education for science (teaching in all possible ways). Haberland (2014: 253-254) highlights that language policies, ideologies and practices differ considerably in these areas. He also adds a fourth area, i.e. administration. He explains that Hamel did not imagine university administration to take place in another language than the country's language of administration, but by now it is becoming a reality at some universities, e.g. in Denmark where some universities are considering the adoption of English as the language of administration.

The above-given distinction between four categories of language practices is useful for understanding the multilingual nature of today's international universities. For example, the language of production of scholarly knowledge can differ from the language of the circulation of knowledge. Moreover, multilingual practices can be observed 
within one category as well. Söderlundh $(2012,2013,2014)$ shows in a series of articles that courses nominally taught in English rarely (if ever) make only use of English. Her research highlights that university teaching consists of discursive practices that are carried out in different languages available to course participants. As a result, she (2012: 90) stresses that internationalisation should be regarded a multilingual rather than a monolingual process.

Although internationalisation of higher education and language matters are inextricably intertwined, the discussion on language does not always occupy a prominent place in internationalisation discourse. Policymakers do not always view language as an issue entitled to special attention. For example, Saarinen and Nikula (2013) and Saarinen (2014) show that language becomes implicit, blurred, and even invisible in Finnish higher education and internationalisation documents, in which policy is otherwise explicitly formulated. According to Saarinen and Nikula (ibid.: 133), languages used to be an intricate part of internationalisation discourse at the onset of such policies in Finland in the 1970s and the 1980s. However, as Saarinen (ibid.: 129) notes, the position of language in higher education policy has since developed into being "unclear and unproblematised".

\section{A brief overview of the higher education systems of Estonia and Latvia}

Altogether, there are 24 institutions of higher education in Estonia and 56 in Latvia. Both Estonia and Latvia are suffering from a demographic low point, and the number of students is falling rapidly in both countries. In Estonia, the number of students has decreased by $26 \%$ since its peak in 2010, and in Latvia, it has shrunk by $36 \%$ since 2005 . Whereas changes in the number of students have affected the higher education system in Estonia (in 2002 there were 49 higher education institutions), the higher education system in Latvia has not been restructured (for example, the number of higher education institutions has not changed at all). This makes Latvian higher education particularly dependent on fee-paying foreign students. Nevertheless, the proportion of foreign students in Estonia and Latvia is roughly the same; in the academic year 2015/2016 almost 7\% of students in Estonia and 8\% of students in Latvia were from abroad (data from the Ministry of Education and Research of Estonia 2016 and the Ministry of Education and Science of Latvia 2016). 
Higher education in Estonia and Latvia mainly functions in the official languages of the countries, Estonian and Latvian respectively. In addition, English and Russian are used as media of instruction. In Latvia, Russian-medium studies are only allowed in private higher education ${ }^{1}$; their popularity has neither significantly increased nor decreased in the last years (altogether approximately $7 \%$ of students are enrolled in Russian-medium programmes). In Estonia, the use of Russian as a language of instruction has been constantly decreasing since the early 1990s (today approximately $2 \%$ of students are enrolled in Russianmedium programmes). By contrast, the popularity of English-medium studies is growing year by year both in Estonia and Latvia. In recent years, the number of students enrolled in English-taught programmes has increased particularly rapidly and English-medium studies have grown more popular than Russian-medium studies. Today approximately $9 \%$ of students in Estonia and Latvia are studying in degree programmes nominally taught in English. The majority of students (approximately $90 \%$ of students in Estonia and $80 \%$ of students in Latvia) are enrolled in programmes that are nominally taught in the official language of the country (data from the Ministry of Education and Research of Estonia 2016 and the Ministry of Education and Science of Latvia 2016)2.

Both Estonia and Latvia have adopted laws that stipulated the use of languages as media of instruction. Whereas in Estonia it is only briefly mentioned in the Universities Act (1995) and in the Institutions of Professional Higher Education Act (1998) that the medium of instruction in public institutions of higher education should mostly be Estonian, Latvian legislation goes into greater details. The Education Law (1998) and the Law on Institutions of Higher Education (1999) stipulate that the main medium of instruction in state-funded institutions of higher education is Latvian. Students in any programme may earn up to one fifth of their credit points for courses held in other official languages of the EU. Thus, Russian is not a possibility, except for foreign

20 institutions of higher education out of 56 are privately funded in Latvia.

2 The official statistics mostly name only one language as medium of instruction, i.e. the one presented in course accreditation documents. However, Söderlundh (2013) and Ljosland (2014) show that grass-root language practices often do not correspond to statistical information that only takes into account the nominal language of instruction. Although a programme or a course may be officially monolingual, in reality, students and faculty tend to make use of a variety of linguistic resources that they possess; actual language practices are often multilingual even in officially monolingual settings. As seen here and discussed below, top-down language policies tend not to take such multilingual practices into account. 
language and culture studies. In addition, the official languages of the EU can be used in programmes in which foreign students study and in programmes which are implemented within international cooperation. As a result, non-Latvian-medium instruction is first and foremost meant for foreign students. Moreover, the law also stipulates that Bachelor's and Master's theses have to be written in Latvian. Furthermore, the Law on Scientific Activity (2005) stipulates that $\mathrm{PhD}$ theses have to be submitted in Latvian or any other official language of the EU if they have an extensive summary in Latvian. Interestingly, whereas the overwhelming majority of $\mathrm{PhD}$ theses defended in Estonia are written in English (Klaas-Lang and Metslang 2015), most PhD theses submitted at Latvian universities are written in Latvian (even on scientific and technical topics) although there are no official regulations that would forbid writing $\mathrm{PhD}$ theses in English or other official languages of the EU (Kibbermann, forthcoming).

\section{Method and data}

The main purpose of the study is to cast light on how Estonia and Latvia handle the question of language in the process of internationalisation of higher education. The data for the analysis were collected from a variety of state-authored policy-planning documents that are not legally binding but contain ideological views on the issue under consideration. The drafting of state-authored policy documents that cover language issues in higher education has been prompted by the need and desire to adapt to a rapidly changing higher education environment.

In order to conduct policy text analysis, a considerable amount of current policy-planning documents was scanned, and a corpus of documents was chosen so that they offered extensive coverage of theinterrelated issues of language and internationalisation in the research settings. The documents analysed are listed in Table 1 . As policy planning documents tend to cover many more issues than relevant for the purposes of this paper, the documents were scanned for keywords (language, Latvian/Estonian, English, Russian, internationalisation, etc.) in order to find passages applicable to the analysis. Some of the documents were directly available in English; when official translations were not available, the equivalent keywords were used in the respective language. As a result, parts of text connected with the research topic were extracted. Finally, the data were analysed by means of qualitative data analysis. 
Table 1. Data: state-authored policy-planning documents in Estonia and Latvia

\begin{tabular}{l|c|r} 
& $\begin{array}{r}\text { Year of } \\
\text { publication }\end{array}$ & $\begin{array}{c}\text { Length in } \\
\text { number } \\
\text { of words }\end{array}$ \\
\hline Estonia & 2011 & 19,474 \\
\hline $\begin{array}{l}\text { Development Plan of the Estonian Language } \\
\text { for 2011-2017 }\end{array}$ & 2006 & 6,321 \\
\hline $\begin{array}{l}\text { Estonian Higher Education Strategy for 2006- } \\
\text { 2015 }\end{array}$ & 2006 & 6,123 \\
\hline $\begin{array}{l}\text { Strategy for the Internationalisation of Estonian } \\
\text { Higher Education over the years 2006-2015 }\end{array}$ & 2014 & 9,861 \\
\hline \begin{tabular}{l} 
The Estonian Lifelong Learning Strategy 2020 \\
\hline $\begin{array}{l}\text { Estonian-language Terminology Programme } \\
\text { 2013-2017 (in Estonian) }\end{array}$
\end{tabular} & 2013 & 3,120 \\
\hline $\begin{array}{l}\text { Estonian Language Textbooks for Institutions } \\
\text { of Higher Education 2013-2017 (in Estonian) }\end{array}$ & 2013 & n.a. \\
\hline Latvia & 2010 & n.a. \\
\hline $\begin{array}{l}\text { Sustainable Development Strategy of Latvia } \\
\text { until 2030 Latvia 2030 }\end{array}$ & 2013 & 20,432 \\
\hline $\begin{array}{l}\text { Latvian National Development Plan for 2014- } \\
\text { 2020 }\end{array}$ & 2012 & \\
\hline $\begin{array}{l}\text { Guidelines for the Development of Education } \\
\text { 2014-2020 (in Latvian) }\end{array}$ & 2013 \\
\hline $\begin{array}{l}\text { The Concept of the Development of Higher } \\
\text { Education and Higher Education Institutions } \\
\text { for 2013-2020 (in Latvian) }\end{array}$ & & \\
\hline
\end{tabular}

Qualitative data analysis is considered a valid method for the purposes of this paper as is it a flexible (Hsieh and Shannon 2005), yet systematic and rule-guided (Mayring 2000) approach to text analysis that can be applied to a wide variety of texts in order to infer both explicit and implicit meanings (Hsieh and Shannon ibid.). Qualitative content analysis is helpful to code copious amounts of textual data, as in the present case, and systematically trace the recurring themes that appear in the material. In the application of qualitative content analysis conventional content analysis was used: after line-by-line reading of the data it was coded from scratch; codes were then clustered into categories based on their similarity and regularity. Finally, these categories 
were compared to generate broader themes that constitute the foundation for interpretation presented below (ibid., Saldana ibid.). As a result, an overarching theme was established for both sets of documents: a) internationalisation is an inevitable part of higher education in the case of Estonian document analysis, and b) higher education has to become more prone to internationalisation in the case of Latvian document analysis.

\section{Analysis}

\subsection{Estonia: Internationalisation is an inevitable part of higher education}

Diverse approaches have been adopted in the analysed policy documents when discussing the role of internationalisation in Estonian higher education. In the majority of the documents, internationalisation of higher education is depicted as an inevitable and inescapable reality of today's academia. For example, the Development Plan of the Estonian Language that otherwise takes a strict approach to maintaining and developing Estonian as an academic language depicts internationalisation and the spread of English in today's higher education as inevitability when describing the Estonian academia as such: 'Because of internationalisation of the academic sphere the role of English-medium education is on the rise, especially on higher educational levels.'

In addition, internationalisation is construed in some documents as an opportunity for the Estonian higher education, yet in others it is indicated as a threat to the existence of Estonian as a full-fledged standard language used in all spheres of life. The precise agenda seems to depend on the objectives of documents. For example, the Strategy for Internationalisation of Estonian Higher Education argues for internationalisation, mentioning many of the common reasons used also elsewhere: inbound mobility, quality of education, improved language and cultural skills of students, better opportunities in the labour market. In addition, the Estonian Lifelong Learning Strategy, which is positioned in its introduction as the most important education strategy that guides the developments in education, explicitly connects academic working and teaching experience in a foreign language to quality. It maintains that an important indicator of the quality of the work of academic staff is their foreign experience, either teaching or working abroad or participation in developing international programmes and foreign-medium curricula. 
Furthermore, internationalisation is construed as a threat for instance in the internationalisation strategy in which its authors admit that mobility of students and faculty brings not only possibilities but also challenges for the Estonian academia. However, this thought is not developed any further than shortly mentioning the importance of preserving Estonian as the primary language of teaching and research. The threats posed by internationalisation are outlined to the greatest extent in the Development Plan of the Estonian Language and the two programmes that are tightly connected to it, the Estonian-language Terminology Programme and the Estonian-language Textbooks for Institutions of Higher Education. The aim of these documents is to strengthen the position of Estonian as an academic language, but at the same time references to the smallness of the Estonian language are made due to which the spread of English is construed as unavoidable. For example, the Estonian-language Textbooks for Institutions of Higher Education claims that by 2030 Estonian higher education would be bilingual in Estonian and English, but in order to maintain the division of languages, the use of and attitudes towards Estonian in academia have to be heavily supported.

When language issues are discussed in the context of internationalisation, the medium of instruction is in the spotlight. For example, it is stressed in the internationalisation strategy that the medium of instruction in Estonia have to become more international. According to the strategy, it is enough to provide Estonian-medium education only at the first two levels of higher education, in Bachelor's and Master's programmes. It does not set any requirements for Estonian-medium instruction at the $\mathrm{PhD}$ level. As a result, a welcoming attitude is adopted in the internationalisation strategy towards foreign-medium instruction and hiring international faculty that are construed as necessities for improving the quality of higher education and engaging international students. The strategy stresses that internationalisation is important for the local students as well, especially for boosting their opportunities in the international labour market. Thus, foreign-medium programmes and courses have to be available for foreign and local students alike in order to improve their conversational skills and to acquire necessary terminology in a foreign language.

The internationalisation strategy explicitly argues for the need to increase the number of course offerings in foreign languages. Although at the teaching level internationalisation of higher education is first and foremost expressed in the growing number of English-taught programmes and courses, the strategy almost always refers to foreign 
languages (mentioned 19 times in the document) instead of English (mentioned explicitly 3 times). The tendency to refer to foreign languages when meaning English has been observed also in the internationalisation and language policy documents of other countries, e.g. Finland. Saarinen and Nikula (2013: 135) note that "the choice of the more general term is probably indicative of a genuine political will to keep possibilities open for the introduction of other foreign language programmes." However, not speaking about the spread of English explicitly makes it discursively and ideologically stronger and more powerful (ibid.: 138). Languages other than Estonian and English are not mentioned in the Estonian internationalisation strategy.

Additionally, the higher education strategy holds that Englishmedium (mentioned explicitly) doctoral studies have to be developed in order to promote mobility and to attract foreign students. Furthermore, it suggests that every field of study has to be available in Estonian. However, the suggestion to preserve Estonian-medium teaching in every field of study does not mean much. According to the international ISCED framework, education is divided into nine broad groups, for example, the humanities and arts being one broad group. These groups are divided into 25 fields of education, for example, the broad group of the humanities and arts is divided into two fields of education: the humanities, and arts. The field of the humanities consists of different curricula, such as religion and theology, mother tongue, and history and archaeology. Thus, according to the higher education strategy, at least one of these curricula has to use Estonian as the medium of instruction while others could be taught in foreign languages.

The suggestion put forward by the internationalisation strategy and the higher education strategy to teach in Estonian in every field of study at Bachelor's and Master's level has caused some resistance. For example, the Development Plan of the Estonian Language explicitly disapproves of the ideas and claims that the two aforementioned strategies are too tolerant of English (mentioned explicitly) and accelerate unnecessarily its spread in Estonian academia. Consequently, the development plan suggests to legalise the Estonian-medium instruction in all groups of curricula at all levels of study and maintains that the proportions of languages used as the media of instruction should be defined in curricula. In addition to paying attention to the medium of instruction, it discusses the language of theses, suggesting to set a requirement that would make all Bachelor's, Master's, and PhD theses written in foreign languages to have Estonian-language summaries (this requirement has been established legally in Latvia). 
Interestingly, when describing the current situation in Estonian tertiary education, the development plan explicitly names three languages - Estonian, English, and Russian - in which the higher education system functions: 'In higher education efforts are made to seek balance between the national and international components, that is, between the functions of Estonian and English; Russian is used, too.' In no other document has Russian been mentioned as a language of higher education in Estonia although it still has some importance in Estonian academic life. Whereas Russian is discussed in the Estonian policy-planning documents in the context of general education, it does not appear in the discussions on higher education (Kibbermann, forthcoming $\mathrm{PhD}$ thesis). Nor does the development plan pay any further attention to Russian but focuses solely on Estonian and English.

\subsection{Latvia: Higher education has to become more prone to internationalisation}

The Latvian documents included in the analysis describe internationalisation of higher education mostly as a necessity for the Latvian state, its economy, and tertiary education. The policy-planning documents that discuss the need to internationalise Latvian higher education pay no attention to unwanted side effects that could possibly be brought about by the processes. Nevertheless, the documents repeatedly point out the need to preserve Latvian and follow the Latvian language policy when internationalising higher education. For example, the National Development Plan, positioned in its introduction as the highest nationallevel medium-term planning document that aims to summarise the state priorities and main areas of action, holds that Latvian is to remain the main language of instruction in higher education. The National Concept of the Development of Higher Education and the Institutions of Higher Education stress the importance of preserving the unique linguistic nature of Latvian higher education while internationalising it.

The most common argument for internationalising Latvian higher education is the need to reach foreign students. Several documents, for example, the National Development Plan, the Sustainable Development Strategy of Latvia until 2030, and the National Concept for the Development of Higher Education and Institutions of Higher Education stress the utmost importance of inbound student mobility in Latvia in order to fill the demographic gap from which the institutions of higher education are severely suffering. Thus, internationalisation of higher 
education is interpreted as the export of higher education, i.e. the main underlying objective seems to be attracting foreign students. Opinions vary on how many foreign students are necessary to fill the local institutions of higher education. For example, the sustainable development strategy is modest in its predictions as it considers it enough for the proportion of foreign students to be approximately $10 \%$ by 2030 in Latvian institutions of higher education (this percentage is soon to be reached); the national concept highlights that by 2020 at least $20 \%$ of students should be from abroad.

As a result of the great need for incoming foreign students, the National Development Plan stresses the importance of providing degree programmes not only in Latvian but also in other official languages of the EU. Commercialisation and export of Latvian higher education receive close attention in the National Development Plan. Means for achieving the objective include the creation of joint programmes in other EU languages in no fewer than ten fields of study (out of 25, according to the ISCED classification) and the recruitment of foreign faculty. The development plan does not openly discuss other aspects of internationalisation, for example, the effects of internationalisation on the quality of higher education or the future prospects of domestic students. Nor does it name the official EU languages that are encouraged to be used, hinting that all of them are equal. In any case, Russian is excluded from becoming a potential medium of instruction in statefinanced tertiary education.

It is quite common in the Latvian policy-planning documents that the need to internationalise higher education is discussed without making extensive references to language matters that accompany the processes. For example, the National Concept for the Development of Higher Education and Institutions of Higher Education that has been drawn up to work towards the long-term objective of the Latvian higher education - to advance Latvian higher education in parallel to developments in Europe, including measures to internationalise the higher education in Latvia, almost never discusses the role of language in the process. Connecting Latvian higher education to that of Europe raises many language-related questions that remain largely unanswered on the 110 pages of this document. Language is mentioned only nine times. Almost all of the mentions occur in reference to other national and EU documents, copying word-for-word what they say about higher education. 
The Guidelines for the Development of Education discuss language in higher education the most. By contrast to other documents, the authors of the education policy guidelines acknowledge that internationalisation may pose challenges to Latvian higher education, but these are not discussed in greater detail. Similarly to other such documents, it is held in the education guidelines that the Latvian higher education has to become internationally competitive. The means to achieve this aim include conducting studies in foreign languages, and increasing mobility. The guidelines stress that Latvian higher education has to become prone to mobility. This suggests that at the time of drafting the document its authors did not see Latvian academia as an environment that would welcome mobility (not enough degree programmes in foreign languages, lack of foreign students). Non-Latvian-medium studies and incoming foreign students are discursively tied to elevated levels of prestige and competitiveness of Latvian higher education.

\section{Discussion and conclusions}

The analysis shows some differences in the role of languages as conceptualised in the state-level policy-planning documents in Estonia and Latvia. Firstly, the internationalisation of higher education is discussed more thoroughly in the Estonian policy documents than in the Latvian material. As a result, the Estonian policy documents include arguments not only for the benefits of internationalisation but also warnings about and even disapproval of the current internationalisation tendencies, including in the sphere of language use. By contrast, the Latvian policy makers advocate the need to internationalise Latvian higher education but often ignore or only superficially touch upon language issues that accompany processes of internationalisation. Furthermore, Latvian government agencies have not drafted a specific strategy for the internationalisation of higher education that could outline their view on language use in higher education, among other topics. Nor do the Guidelines of the State Language Policy for 2015-2020, positioned as the main language policy planning document in Latvia by its authors, discuss language matters in higher education.

Secondly, the analysis indicates that the internationalisation of higher education mostly serves the economic interests of the countries and universities in global competition as utmost urgency to fill institutions of higher education with foreign students prevails both in Estonia 
and Latvia. Arguments according to which an equal sign is put between internationalisation and quality of education, students' improved language and cultural skills and enhanced opportunities in the labour market make an appearance from time to time in both sets of documents. However, when internationalisation is discussed, the greatest share of attention is paid to the issue of language of instruction. The medium of instruction is directly connected to inbound student mobility as neither Estonian nor Latvian government offices seem to expect the majority of incoming students to study in the official language of the country. Even though internationalisation is tightly linked to English-medium instruction in both countries (this is mirrored well in the official statistics on the media of instruction), neither Estonian nor Latvian policy documents speak directly about the spread of English in academia. Instead internationalisation is first and foremost expressed by instruction in foreign languages in the case of Estonian data and in the official EU languages in the Latvian set of data.

Finally, the results of the analysis suggest that particular stress is put on the medium of instruction when discussing language matters in processes of internationalisation. As a result, language use in academia is viewed in a rather traditional manner. The documents tend to depict languages as discrete entities with concrete borders - at a time one or another language can be used for fulfilling a certain function. However, studies on language use in academia (Söderlundh 2012, 2013, 2014, Ljosland 2014, and Kibbermann forthcoming) show that languages are rarely (if ever) used in such a manner and processes of internationalisation are multilingual at all levels - people make use of a great deal of linguistic resources they possess at all times. For example, language of instruction is not a solid concept at the grassroots level. The fact that one language has been chosen as the nominal language of instruction does not mean that other languages are not used in the teaching process. Furthermore, the medium of instruction is only part of the language use in academia. Languages fulfil a multitude of functions in university settings, for example, they are used for communication with co-students, colleagues and university administrations, reading literature, carrying out research and writing papers, etc. The actual language use is much more diverse than depicted in policy documents. 


\author{
Address: \\ Kerttu Kibbermann \\ University of Latvia \\ Faculty of Humanities \\ Visvalža iela $4 a-316$ \\ LV-1050 Riga, Latvia \\ E-mail: kerttu.kibbermann@1u.lv
}

\title{
References
}

Coleman, James A. (2006) "English-medium teaching in European higher education". Language Teaching 39, 1, 1-14.

Haberland, Hartmut and Bent Preisler (2015) "The position of Danish, English and other languages at Danish universities in the context of Danish society". In F. Xavier Vila and Vanessa Bretxa, eds. Language policy in higher education: The case of mediumsized languages, 15-42. Bristol: Multilingual Matters.

Haberland, Hartmut (2014) "English from above and below, and from outside". In Anna Kristina Hultgren, Frans Gregersen, and Jacob Thøgersen, eds. English in Nordic universities: Ideologies and practices, 251-263. Amsterdam/Philadelphia: John Benjamins Publishing Company.

Hamel, Rainer E. (2006) "Spanish in science and higher education: Perspectives for a plurilingual language policy in the Spanish-speaking world". Current Issues in Language Planning 7, 1, 95-125.

Hazelkorn, Ellen (2011) Rankings and the reshaping of higher education: The battle for world-class excellence. Basingstoke: Palgrave.

Hsieh, Hsiu-Fang and Sarah E. Shannon (2005) Three approaches to qualitative content analysis. Qualitative Health Research 15, 9, 1277-1288.

Hultgren, Anna Kristina (2014) "English language use at the internationalised universities of Northern Europe: Is there a correlation between Englishisation and world rank?" Multilingua 33, 3-4, 389-411.

Jensen, Christian and Jacob Thøgersen (2011) "Danish university lecturers' attitudes towards English as the medium of instruction." Iberica 22, 13-34.

Kibbermann, Kerttu (forthcoming) Languages in higher education in Estonia and Latvia: From regulations to practices. Forthcoming $\mathrm{PhD}$ thesis. Riga: University of Latvia.

Klaas-Lang, Birute and Helle Metslang (2015) "Language policy and sustainability of Estonian in higher education". In Gerhard Stickel and Cecilia Robustelli, eds. Duisburger Arbeiten zur Sprach- und Kulturwissenschaft / Duisburg Papers on Research in Language and Culture, 161-177. Frankfurt am Main: Peter Lang Verlag.

Lam, Queenie K.H. and Bernd Wächter (2014) "Executive summary". In Bernd Wächter and Friedhelm Maiworm, eds. English-taught programmes in European higher education. The state of play in 2014. ACA papers on international cooperation in Europe, 15-24. Bonn: Lemmens. 


\section{Kerttu Kibbermann}

Ljosland, Ragnhild (2014) "Language planning confronted by everyday communication in the international university: the Norwegian case". Journal of Multilingual and Multicultural Development 35, 4, 392-405.

Mayring, Philipp (2000) "Qualitative content analysis". Forum qualitative sozialforschung/forum: Qualitative social research, 1, 2, Art. 20.

Ministry of Education and Research of the Republic of Estonia (2016) Eesti hariduse infosüsteem [Estonian Education Database]. Available online at $<$ www.haridussilm.ee>. Accessed on 07.09. 2016.

Ministry of Education and Science of the Republic of Latvia (1999-2016) Pārskati par Latvijas augstāko izglìtību. Galvenie statistikas dati [Overview of higher education in Latvia. Statistical data]. Available online at <http://www.izm.gov.lv/lv/ publikacijas-un-statistika/statistika-par-izglitibu/statistika-par-augstako-izglitibu> . Accessed on 08.09.2016.

Saarinen, Taina and Tarja Nikula (2013) "Implicit policy, invisible language: Policies and practices of international degree programmes in Finnish higher education". In Aintzane Doiz, David Lasagabaster, and Juan Manuel Sierra, eds. English-medium instruction at universities: Global challenges, 131-150. Bristol: Multilingual Matters.

Saarinen, Taina (2014) "Language ideologies in Finnish higher education in the national and international context: A historical and contemporary outlook". In Anna Kristina Hultgren, Frans Gregersen, and Jacob Thøgersen, eds. English in Nordic universities: Ideologies and practices, 127-146. Amsterdam/Philadelphia: John Benjamins Publishing Company.

Saldana, Johnny (2009) The coding manual for qualitative researchers. London: Sage Publications.

Söderlundh, Hedda (2012) "Global policies and local norms: sociolinguistic awareness and language choice at an international university". International Journal of Sociology of Language, 87-109.

Söderlundh, Hedda (2013) "Language choice and linguistic variation in classes nominally taught in English". In Hartmut Haberland, Dorte Lønsmann, and Bent Preisler, eds. Language alternation, language choice and language encounter in international tertiary education, 85-102. Berlin: Springer.

Söderlundh, Hedda (2014) "Zooming in on language practices in Swedish higher education: A discussion of five studies and their normative versus dynamic approach towards policy and practice". In Anna Kristina Hultgren, Frans Gregersen, and Jacob Thøgersen, eds. English in Nordic universities: Ideologies and practices, 111-126. Amsterdam/Philadelphia: John Benjamins Publishing Company.

Soler-Carbonell, Josep, Taina Saarinen, and Kerttu Kibbermann (2016) "Multilayered perspectives on language policy in higher education: Finland, Estonia and Latvia in comparison". Journal of Multilingual and Multicultural Development, June 24, 1-14.

Spolsky, Bernhard (2009) Language management. New York: Cambridge University Press.

Wächter, Bernd and Friedhelm Maiworm, eds. (2014) English-taught programmes in European higher education. The state of play in 2014. ACA papers on international cooperation in Europe. Bonn: Lemmens. 
Kokkuvõte. Kerttu Kibbermann: Kõrghariduse rahvusvahelistumine ja keelepoliitika Eestis ja Lätis. Artiklis analüüsitakse kõrghariduse keelepoliitikat Eestis ja Lätis. Mõlemad riigid püüavad hetkel leida kõrghariduses tasakaalu rahvusliku ja rahvusvahelise vahel. Kõrgharidus toimib Eestis ja Lätis peamiselt riigikeeles, vastavalt eesti ja läti keeles, aga kasutatakse ka teisi keeli, peamiselt inglise ja vene keelt. Artiklis analüüsitakse võrdlevalt Eesti ja Läti poliitika planeerimise dokumente eesmärgiga välja selgitada, kuidas lähenetakse keeleküsimusele kõrghariduse rahvusvahelistumise poliitikas. Dokumendianalüüs näitab, et kõrghariduse rahvusvahelistumise poliitikas on keeleküsimustele pööratud Eestis rohkem tähelepanu kui Lätis. Sarnasusena võib välja tuua mõlema riigi demograafilise probleemi, mis tundub olevat rahvusvahelistumist käivitavaks teguriks. Sellepärast on rahvusvahelistumine nii Eesti kui ka Läti riiklikus poliitikas peamiselt seotud õppekeele küsimusega.

Märksõnad: kõrghariduse rahvusvahelistumine, keelepoliitika, riiklikud poliitika planeerimise dokumendid, õppekeel, ingliskeelne õpe 